GUMBOSKI, Leandro; ZOMER, Ana Letícia e MOREIRA, Adriana. 2018. Readings of a Work: a musical analysis of All Round Me by Russell Pinkston. MUSICA THEORICA. Salvador: TeMA, 201803, p. 68-96.

MUSICA THEORICA 201803

SCIENTIFIC ARTICLE

Data do recebimento: 20/07/2018

Data da aprovação final: 18/08/2018

\title{
Readings of a Work: a musical analysis of All Round Me by Russell Pinkston
}

\author{
Leituras de uma obra: uma análise musical de \\ "All Round Me" de Russell Pinkston
}

\section{Leandro Gumboski}

Universidade de São Paulo/Instituto Federal do Paraná

leandro.gumboski@usp.br/leandro.gumboski@ifpr.edu.br

\section{Ana Leticia Crozetta Zomer}

Universidade de São Paulo

analeticiazomer@gmail.com

\section{Adriana Lopes da Cunha Moreira}

Universidade de São Paulo

adrianalopes@usp.br

\begin{abstract}
In this paper, we analyze the electroacoustic composition All Round Me by Russell Pinkston. We present three main analytical aspects: (1) identification and classification of materials of each section based on Dennis Smalley's theory of spectro-morphology and Michel Chion's metaphorical description of sound objects; (2) representation of materials through graphical transcriptions to illustrate the structuring and transformation of these materials throughout the work; (3) narrative description based on the idea of representation of spiritmanifestations. Sonographic and spectral analyses were used as support for the spectromorphological identification of sound objects. We sought to demonstrate that the listener of All Round Me is an active participant while being a subject of discourse, confronting throughout the aesthetic experience of the composition with the tension between life and death represented by the states of closeness and remoteness from (sound) spirit-manifestations.
\end{abstract}

Keywords: Electroacoustic music analysis; spectro-morphology; narrative analysis; sonographic analysis; graphical transcription. 

musical analysis of All Round Me by Russell Pinkston. MUSICA THEORICA. Salvador: TeMA, 201803, p. 68-96.

Resumo: Neste texto analisamos a composição eletroacústica All Round Me de Russell Pinkston. Apresentamos ao longo do artigo três principais perspectivas de análise para a peça: (1) identificação e classificação de materiais ao longo de cada seção, com embasamento na teoria de espectro-morfologia de Dennis Smalley e na de descrição metafórica de objetos sonoros de Michel Chion; (2) representação destes materiais através de gráficos de transcrição a fim de ilustrar a estruturação e transformação dos mesmos ao longo da obra; (3) descrição narrativa baseada na ideia de representação de manifestações espirituais. Análises sonográficas e espectrais foram utilizadas como apoio para a identificação espectro-morfológica dos objetos sonoros. Procuramos demonstrar que o ouvinte de All Round Me tem participação ativa ao se colocar como sujeito do discurso, deparando-se ao longo da experiência estética da composição com a tensão entre vida e morte, representada pelos estados de aproximação e afastamento de manifestações (sonoras) espirituais.

Palavras-chave: Análise de música eletroacústica; espectro-morfologia; análise narrativa; análise sonográfica; gráfico de transcrição.

\section{1 - Introduction}

All Round $M e^{1}$ is an electroacoustic ${ }^{2}$ piece that was created in $1997^{3}$ by the American composer Russell Pinkston ${ }^{4}$. Pinkston explores the theme of spirituality in this piece, or more accurately that "the living are surrounded by spirits of the

\footnotetext{
${ }^{1}$ Silvio Ferraz, presenting an analytical reading of works based partly on the concept of sound objects by Pierre Schaeffer, considers the title of a composition as a possible source for the construction of a typology: "Orthodox analysts may prefer not acknowledge the title of the work, especially what they might call a fantasy title. [...] Some titles do not refer so clearly to forms and end up linking to a more open imaginary universe." (Ferraz 2008, p. 87).

2 We understand by "electroacoustic works those that do not have notation, being fixed directly in the support. Acousmatic works [in turn] do not show the origin of the presented sounds, being realized only by means of loudspeakers" (Fenerich 2005, p. ii). It is important to mention that for this analysis we will use the version found in Russell Pinkston: Four Electroacoustic Dance Suites. CDCM Computer Music Series, Vol. 34, Centaur Records, 2005. Available in: $<$ https://soundcloud.com/russell-pinkston/all-round-me $>$. Access on: 07-17-2018.

${ }^{3}$ Due to the infamous September 11, 2001, All Round Me was revised in 2004. Pinkston replaced the original text with the whispered names of the nearly 3000 people who died at the World Trade Center. For him, "their spirits (and/or indelible memories of what happened to them) surround us in the very way that this piece is trying to suggest" (Pinkston 2018).

${ }^{4}$ A Doctor of Music from Columbia University (1984), Russell Pinkston is a composer and active researcher in computer music, who "composed music in a wide variety of styles and genres from choral, chamber and symphonic works, to the electronic music for modern dance. In recent years, he has specialized in writing interactive compositions for acoustic instruments and electronic sounds, and he has developed a number of software tools for real-time audio processing and score following" (Pinkston 2018). His compositions have been played in Europe, South America and the United States, receiving several prizes. Founding member and former president of the Society for Electro-Acoustic Music (SEAMUS), also was director of the Electronic Music Studios at the University of Texas at Austin, where he taught from 1983 to 2018.
} 

musical analysis of All Round Me by Russell Pinkston. MUSICA THEORICA. Salvador: TeMA, 201803, p. 68-96.

dead" (Pinkston 2018). Sounds are interactively articulated to construct a musical narrative flow. Pinkston relies on this metaphor to encourage the listener to follow a narrative ${ }^{5}$ : the tension between life and death is represented by closeness and remoteness states from (sound) spirit-manifestations that surround the person. At first this association may disrupt the purpose of pure acousmatic listening, however, the narrative elements are metaphors that form a conceptual layer in which a network of operations at different time scales makes the perception of sounds more intimate within the material (Svidzinski and Bonardi 2016, p. 71).

We start from the assumption that a single work can be analyzed in different ways i.e., the same piece can elicit different readings. Therefore, in this analysis we seek to emphasize questions about the material identified in each section, on the spectro-morphology of these materials, as well as on their transformation throughout each movement, i.e., how the composition gesturally develops its own narrative.

Of the wide range of analytical theories that exist for electroacoustic music, the French branch of Pierre Schaeffer and Michel Chion (1983) and English brand of Dennis Smalley (1997) are, perhaps, the most recognized and used today. According to Carole Gubernikoff (2007) one of the fundamental differences between the two perspectives is that the sound object in Smalley (1997), replacing the verbal sign, is understood as having a double articulation: it is orientated to its exterior, something related to its own source origin - source bonding - but it is also directed to the interior of its own sound, i.e., its spectromorphology. From Chion (1983) we use mainly the principle of metaphorical description of sound objects. In this context sound objects are not only images of a source, but also "their concrete presence in the imagination (or imaginary) of the listener, since they represent a real physical aspect of a perception of this object" (Fenerich 2005, p. 35).

It is important to note that, in the musical analysis of electroacoustic music, the analyst is constantly faced with the condition of not having visual support for operating the analysis. The sound that comes to us is the work itself, without intermediation ${ }^{6}$. Denise Garcia $(2001,1998)$ lists four possible types of visual encodings in electroacoustic music that correspond to different functions: (1) the annotations, diagrams, graphs, iconic notations or scripts in the conception of the piece; (2) the coding of operations throughout the

\footnotetext{
5 "Each song draws a specific place, a place of listening where the 'listening being' goes." (Ferraz 2007, p. 91).

6 "François Delalande highlights the passage of music written on sheet music (instrumental music) to music written directly on the support (electroacoustic music) as a revolution in the history of music, comparable to the passage from the oral music tradition to the written tradition in the thirteenth century (Delalande apud Garcia 1998, p. 122).
} 

musical analysis of All Round Me by Russell Pinkston. MUSICA THEORICA. Salvador: TeMA, 201803, p. 68-96.

compositional process; (3) mixing plans and graphic signs for a performer that eventually play along (on live electronics performances); (4) graphical transcriptions written for either expert or lay listeners. The first three are nonpublic work tools that are only part of the composer's process of creation and realization of the piece. Finally, the fourth type is intended to increase reading comprehensibility upon receiving the piece, it is "an analytical tool that allows a researcher to refine his listening of the work by attempting to distinguish which graphic can be associated to which sound and why" (Couprie 2004, p. 111). "The graphic signs are like metaphors that refer directly to the image of the sound without so many mediations that the reading of a text demands" (Garcia 2008, p. 81). However, the graphical transcription is a reading of a work, a subjective task, "it is a symbolic representation among so many other possible ones" (Tiffon apud Garcia 2008, p. 90)7.

We also assume that it is possible to describe a narrative for All Round Me from the precepts described by Giomi and Ligabue (1998), Byron Almén (2003, 2008), and Rosalyn Coull (2015). "Musical narrative is the process through which the listener perceives and tracks a culturally significant transvaluation of hierarchical relationships within a temporal span" (Almén 2003, p. 12). According to Giomi and Ligabue (1998), narrative strategies presented in works of electroacoustic music are often derived from those found in traditional instrumental music. We illustrate this principle by trying to demonstrate throughout the paper that there is material development as well as a clear formal structure in Pinkston's composition. However, to do so, we must take note of and analyze - three structural levels: "that of sound objects, that of elementary patterns (i.e., organizations, structures) combining sound objects, and that of patterns of patterns (that last one being an analysis of musical form)" (Thoresen; Hedman 2007, p. 130). Such a theoretical basis will serve throughout this article to support the aforementioned external relations to sound itself, namely its spiritual origin. We begin, in fact, with the statement made by the composer himself in a program note (Pinkston 2018). However, as Almén suggests, it should be noted that

when a listener is previously familiarized with a program, the relationships between word and music are often quite clear. [...] It is not true that a program is an arbitrary appendage; instead, "hooks" in the musical texture seem to form the precondition for a narrative framework (Almén 2003, p. 13).

\footnotetext{
${ }^{7}$ For better fruition of this analysis, we recommend that the reader see/hear the video version of the graphical transcription developed by the authors. Available in: <https://youtu.be/zmAQh1snME $>$. Access on: 11-22-2018.
} 
GUMBOSKI, Leandro; ZOMER, Ana Letícia e MOREIRA, Adriana. 2018. Readings of a Work: a musical analysis of All Round Me by Russell Pinkston. MUSICA THEORICA. Salvador: TeMA, 201803, p. 68-96.

The sonograms we present here were developed with SONAR 8.5 Producer software; the spectral analysis images were made with S_Tools (STx) - a program developed by the acoustics department of the Austrian Academy of Sciences; the graphical transcription, in turn, were illustrated in Microsoft Office Excel ${ }^{8}$ following four steps: "a first quick annotation of the material's main features, a precise segmentation of the sounds or basic sound structures, an analysis of the structures and a final representation of the analysis" (Couprie 2004, p. 111).

Neither listen to structures, intending to behave intelligently, nor get carried away in sentimentality, or to decipher an anecdote, but simply to keep an eye out, turn your ear and let yourself be carried or penetrated by sound images, letting them also compose and recompose their peers of a listening typology (Ferraz 2008, p. 97).

\section{2 - Analysis of All Round Me (1997) by Russell Pinkston}

All Round Me was composed for the choreographer and dancer Andrea Beckham (Sharir Dance Company) ${ }^{9}$ and is structured in six movements entitled (1) All Round Me, (2) Cool Mist, (3) Sudden Rain, (4) Tree Colors Darkening, (5) The Monastery and (6) A Bonging of Bells and were inspired on the ancient poem Sudden Rain by Ni Chia-Ching (Pinkston 2018) ${ }^{10}$. The total time of the piece is 14 minutes and 40 seconds (Pinkston 2005). The sonogram of Figure 1 shows the division of total time into the six movements of the composition. It is observed that, in general, there is a certain balance between the sections so that the one that entitles the work - All Round Me - is, in fact, the longest.

\footnotetext{
8 When searching for software for the creation of graphical transcriptions, we encountered Acousmographe and EAnalysis. When interacting with the Acousmographe software, we perceived a lack of sophisticated graphical resources necessary to fit the complexity of the analyzed piece. In turn, EAnalysis was developed only for Mac OS. Therefore, Microsoft Office Excel became an appealing alternative to develop illustrations due its significant graphic production capabilities. 9 "In performance, the music is controlled by a software written in Max/MSP, which interprets signals coming from a touch-sensitive dance floor and a video tracking system, and reacts to them in various ways, generating and/or controlling both music and video images. Consequently, no two performances are exactly the same". (Pinkston 2018).

10 "All of sudden / rain / brooks roaring. / Mist cool / tree colors darkening / I don't know where the monastery is / until suddenly / it sends out / a bonging of bells / all round me". Tradução de C.H. Kwock e Vicent McHugh (Pinkston 2018).
} 

musical analysis of All Round Me by Russell Pinkston. MUSICA THEORICA. Salvador: TeMA, 201803, p. 68-96.

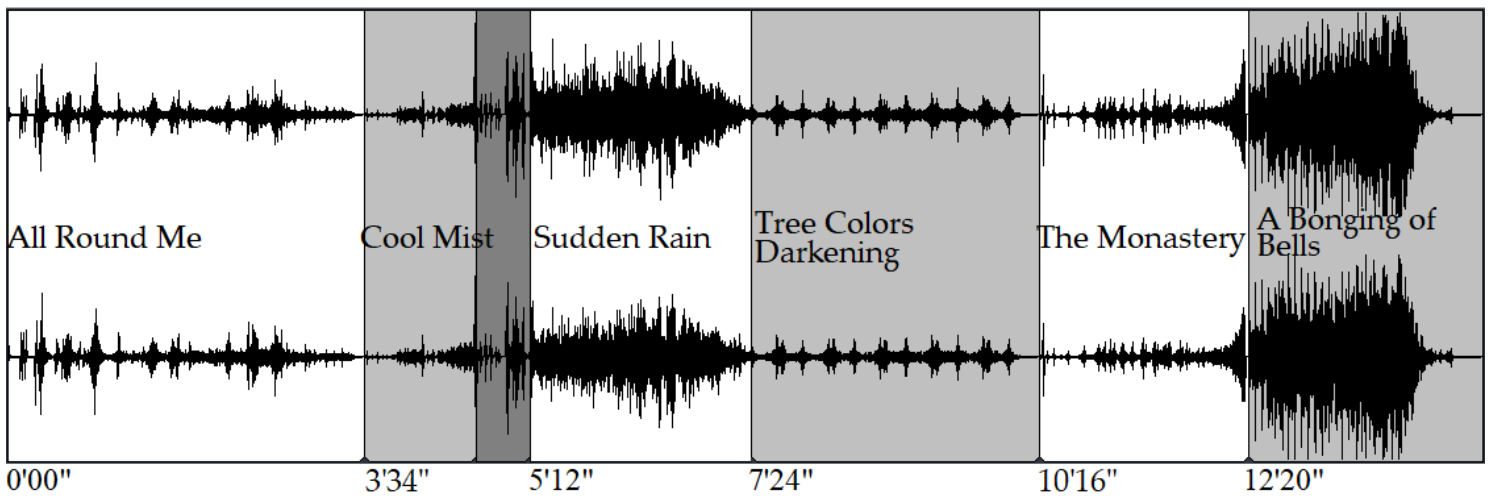

Figure 1: Sonogram, $0^{\prime} 00^{\prime \prime}-14^{\prime} 40$, display of a six parts formal structure

In the following sections of this article, we analyze each movement of the composition. The time reference for each section is identified on the figure description. The time definition of sections marked on Figure 1 is part of our analysis, and may diverge from other analytical papers and references.

The acousmatic sound, like the poetic image, leads to various daydreams that, although in a first stage are real and constitute a common intersubjective field, are ultimately particular to each listener. These daydreams are driven by characteristics proper to sound, imprinted on the support and therefore immutable; they occur when imagining its supposed source, its trajectory, or the space in which it happens (Fenerich 2005, p. 22).

\section{1 - All Round Me: 0'00" - 3'33"}

Of all spirit-manifestations, the simplest and most frequent are those which are made audibly, by raps, or by other noises. [...] Spirit sounds, however, are usually of a peculiar character; they have an intensity and a character of their own, which, notwithstanding their great variety, can hardly be mistaken, so that they are not easily confounded with common noises, such as the creaking of wood, the crackling of a fire, or the ticking of a clock; spirit-raps are clear and sharp, sometimes soft and light, sometimes loud and distinct, sometimes even noisy; changing their place, and recurring, without any mechanical regularity (Kardec 1986 [1861], p. 81-82).

The Mediums' Book published in 1861 by Allan Kardec (pseudonym of H. L. D. Rivail) is one of the great inaugural works of the Spiritist doctrine, from which the epigraph of this subsection was extracted. Among other aspects, Kardec emphasizes the possibility of spirits being manifested sonorously. However, according to the author, the spectro-morphological ${ }^{11}$ characteristics of these sounds are absolutely unique, and there is no direct correlation with natural

${ }^{11}$ We adopt Smalley's (1997) definition of spectro-morphology. 
GUMBOSKI, Leandro; ZOMER, Ana Letícia e MOREIRA, Adriana. 2018. Readings of a Work: a musical analysis of All Round Me by Russell Pinkston. MUSICA THEORICA. Salvador: TeMA, 201803, p. 68-96.

sounds. The possibility of aesthetically exploring unusual, unnatural, synthesized or electronically manipulated sounds is precisely one of the defining features of Postwar musical production. Thus, we take the description presented by Kardec as a starting point for the analysis of the sound objects found in All Round Me. From this, we maintain in this paper that the sound objects experienced in All Round Me are representations of spirit-manifestations.

The "sound raps" idea, to which Kardec refers, is constantly explored throughout the composition. We consider "sound rap" as the associative result to the physical act "to knock", as for example that of a door being closed abruptly. The result is a sound that if analyzed in terms of its sound envelope (ADSR), or onset-continuant-termination as Smalley (1997) indicates, usually has a relatively rapid, sudden attack. However, some of these transient sounds usually have a broad spectrum of frequencies, especially from a low band. In addition to these parametric characteristics, it is common for sound intensity to be identified at high values. There is not, according to Kardec (1986 [1861]), an exact copy of everyday sounds, although the spontaneity of some of these sounds could already be, in a way, the spiritual manifestation itself. However, the listener's interpretive correlation with the unnatural movement of everyday objects is practically immediate.

This happens in the first movement of Pinkston's composition, All Round Me. We identify five categories of material in this section, and these are transformed or recapitulated throughout the work: four objects of the type "sound rap" and the whispered human voice typically used for the representation of spirits by the human imagination.

At the beginning of the composition, the four materials, but the human voice, are presented to the listener. To facilitate the description, we identify these objects as $a, b, c$ and $d$, but we also do, as Chion (1983) suggests, a metaphorical description for each of them. The first one sounds like a wooden tool falling on the strings of a piano. We believe that the process of creating this sound object was, in fact, something similar to this description. However, this same metaphor assumes an important function in the narrative framework, since the spontaneity of the process itself is recognized by the listener as a spiritual manifestation. It is therefore a transient sound as previously described, but with considerable sustain especially in the low frequency spectrum.

The second object - $b$ - sounds like (although there are substantial differences) the friction caused by the drag of the table legs on the floor. Although we use this metaphorical description, the composition of this sound object may also have been produced by the friction of a metallic object on the piano strings. This element is explored more continuously, filling spaces between occurrences of $a, c$, and $d$. The third material - $c$-, in turn, resembles an odd stroke (e.g. 20", $33 ", 3 ")$ or double stroke (e.g. 52", 2'47", 3') of varied dynamics on low frequencies 
GUMBOSKI, Leandro; ZOMER, Ana Letícia e MOREIRA, Adriana. 2018. Readings of a Work: a musical analysis of All Round Me by Russell Pinkston. MUSICA THEORICA. Salvador: TeMA, 201803, p. 68-96.

of the spectrum. This element is presented at the beginning of the composition with simultaneous onsets to material $b$.

The fourth material - $d-$, which operates on a considerably higher register of the spectrum than the other materials, vaguely resembles a rattle, although its manipulation throughout the composition brings it, spectro-morphologically, closer to the whispered voice (the fifth element of All Round $\mathrm{Me}$ ) especially because they share relatively close frequency bands. Finally, there is a separate material - $e$ - which appears to be an instrument string (guitar, piano) being scraped that metaphorically can be associated by the listener with a, spiritually realized, action such as the creaking of wooden objects or door hinges. This latter material does not present itself with the same frequency or the same evidence as the other materials and is used to fill small spaces of the spectrum at times that the listener attention is likely to be directed to other sound objects. This material can also be understood as a derivation of the previous element $b$.

We represent these materials in the graphical transcription with the aim of increasing reading comprehensibility (see Figure 2). We try to classify the elements in high, mid and low sounds in a temporal plane measured in seconds. We chose different colors and shapes for each material: object $a$ - dark blue; object $b$ - yellow; object $c$ - black; object $d$ - red; object $e$ - brown; whispered voices - light gray; and wind chime - turquoise. Throughout the piece, these materials are continuously transformed. We intend to show the most explicit transformations through the variation of colors (weak and strong) for dynamics and the configuration of the objects for the variation of spectro-morphological categories. There is, nevertheless, a profusion of varied sounds throughout the work, so we limit ourselves to present only those that we consider most pertinent to the analytical context of each movement. There are still other materials that echo along a section; these are indicated by the colors pink, purple and blue at the top of the graph.

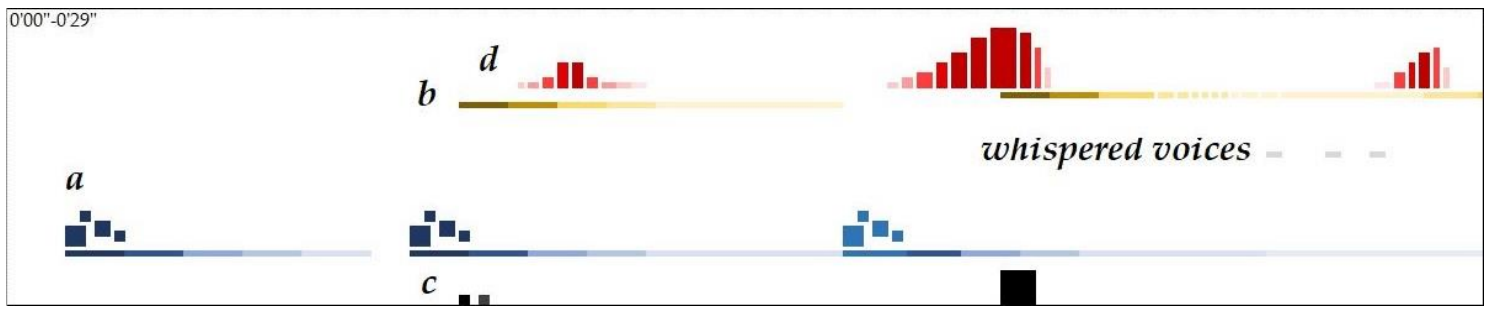

Figure 2: Graphical representation, $0^{\prime} 00^{\prime \prime}-0^{\prime} 30^{\prime \prime}$, presentation of materials

The materials $a, b, c$, and $d$, which together make up a single gesture, are resumed countless times in modified manners, by changing different parameters. These four elements are juxtaposed only at the beginning of the section and then overlapped progressively to create new textures. The whispered voice is added 

musical analysis of All Round Me by Russell Pinkston. MUSICA THEORICA. Salvador: TeMA, 201803, p. 68-96.

to these gestural movements and it gradually comes to the foreground. This movement happens by two factors: the increase of the time span of the other four elements $a, b, c$, and $d$ (that gradually appear at longer time intervals), and the intensification of the voices density (that begins with a single whisper [by 25"]) that gradually transforms into a dense overlap of whispered vowel fragments throughout the work [mainly between 2' - 2'30"]).

"Let us then take one of the characteristics of electroacoustic music, that of 'providing the composer with the recording, arrangement and mastery of an internal space to the work'" (Chion apud Fenerich 2005, p. 22). Space is composed of images, by the meeting and the movement of these images. There are spaces with images of more or less permanence and spaces of different speeds. Two strategies are recognized: direct reiteration and resonance; echo and reverberation (Ferraz, 2007, p. 92). In this way, we observe the formation of two spaces $^{12}$ in All Round Me: (1) the intimate space of the individual, which deals with the approximation of spirits through direct, non-distant, almost invasive sound manifestations; and (2) the distance space, sometimes through resonance, enhancing the distance between the individual and the sound manifestation. There is, in this process, a matter of spatiality, which is a fundamental issue for the aesthetic of the genre and will be revisited at the conclusion of the paper.

Figure 4 shows a new material in turquoise at $47^{\prime \prime}$. This shiny, grainysounding material gradually changes over the whole movement, up to 2'50", when it stands out for recalling the sonority of wind chimes. In many cultures, especially Latin, the wind chimes are considered to have the function of "scare the spirits", due to the belief that the instrument drives away the spirits of the dead. At the end of the movement, the wind chime sound ceases, fading-out together with a density decrease of the whispered voices and of the material $c$, leading to absolute silence at 3'33". The sonogram of Figure 3 and the graphical transcription of Figure 4 illustrate these actions, identifying each element by the codes defined early on.

12 "The space will be understood only as being what makes one notice the existence of a place which, in the case of musical composition, makes the composer responsible for drawing the place where the listening is done" (Ferraz 2007, p. 91). 

musical analysis of All Round Me by Russell Pinkston. MUSICA THEORICA. Salvador: TeMA, 201803, p. 68-96.

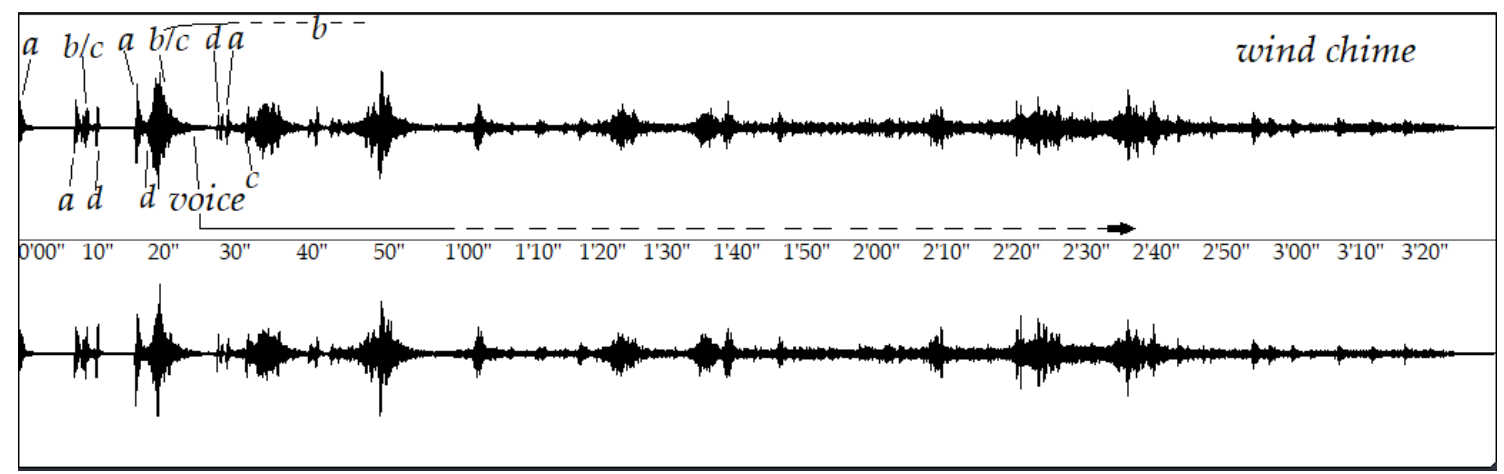

Figure 3: Sonogram, $0^{\prime} 00^{\prime \prime}-3^{\prime} 33^{\prime \prime}$

Concerning the symbolic narrative of this movement we would like to make one last observation, especially in relation to its closure. It seems to us that the presence of the wind chime sound is purposeful. We separate this element to support the premise that the sounds experienced in All Round Me are representations of spirit-manifestations. The wind chime is actually an exception. However, this exception becomes an essential premise for the composition narrative, since the more prominent this element sounds, the more voices fade. Nevertheless, the wind chime fulfills its role only at finishing of this movement that purposely ends in 3'33". The time of 3:33 a.m. is singular, weighted in the popular imaginary as the "hour of death", for many reasons. It is understood as the specific moment when the division between the world of the living and the dead becomes tenuous (Magliocco 2004). This fact aesthetically justifies the return of the material "whispered voice" - as a spiritual manifestation - as a preponderant element in the next section of the composition.

There are still some considerations on the spectral handling of All Round Me. When looking at the sonogram of Figure 3, we note that the amplitude remains more or less constant with the highest peaks between 15" and 50". However, the spectrum gradually enlarges at this section until it takes on a very distinct morphology at the end of the movement. This amplification of the spectrum for higher bands results psychoacustically in approaching the listener with the material whispered voices as spirits-manifestations. Figure 5 shows that, of the starting materials $(a, b, c$, and $d), d$ is the one with the broadest spectrum, although operating on a substantially higher region. The low and loud raps, as described by Kardec (1986 [1861]), are assumed by $a$ and $c$. The materials presented in this movement are reiterated throughout the work, mainly the element $c$, which gives great cohesion to the composition, since they make up the first gesture that is heard in All Round Me. 
GUMBOSKI, Leandro; ZOMER, Ana Letícia e MOREIRA, Adriana. 2018. Readings of a Work: a musical analysis of All Round Me by Russell Pinkston. MUSICA THEORICA. Salvador: TeMA, 201803, p. 68-96.

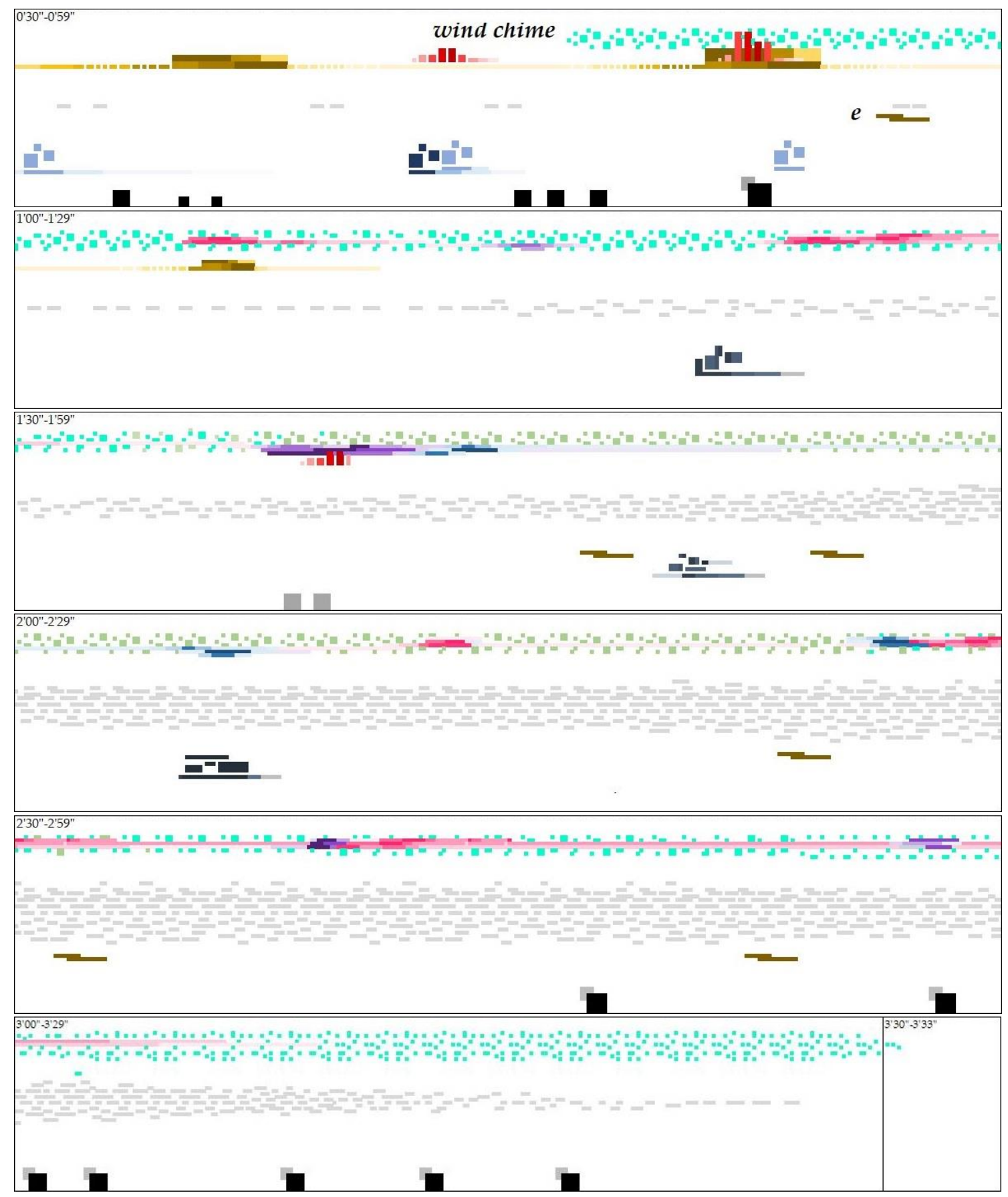

Figure 4: Graphical representation of structuring materials, $0^{\prime} 30^{\prime \prime}-3^{\prime} 33^{\prime \prime}$ 


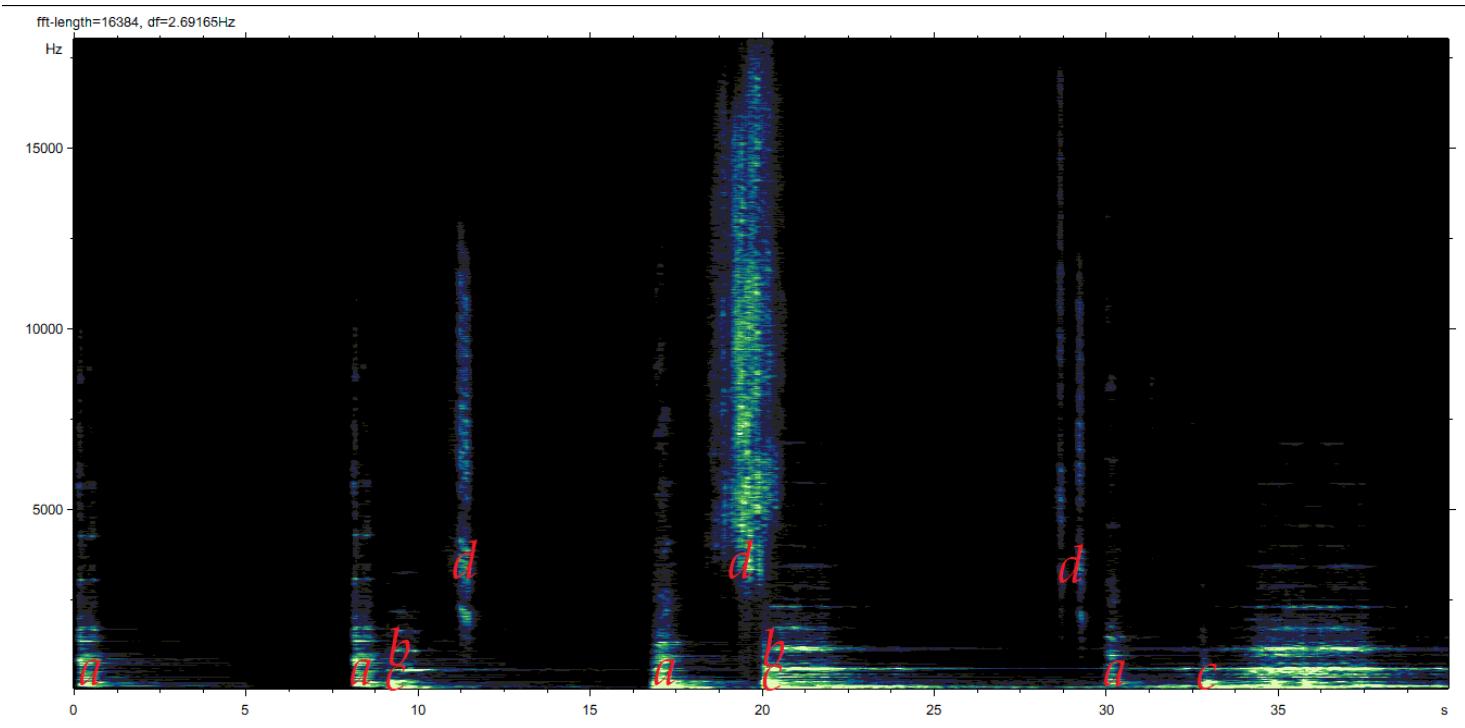

Figure 5: Spectrum Analysis (20Hz-18KHz), 0'00"- 0'40"

Figure 5 also demonstrates a first principle of material variation and development: permutations of the initial gesture composed of materials $a-b / c-d$. We have heard at least two more clear variations of this gesture in the first third part of this section (between $00^{\prime} 00^{\prime \prime}$ and 1'00" approximately), beyond the original format $a-b / c-d: a-d-b / c ;(b) d-a-c-b$. This arrangement of distinct permutations is combined with the input of the element "whispered voice", parametric variations and expansion of the frequency spectrum for higher bands. Figure 6 illustrates this spectrum expansion in the middle of this first movement. This expansion happens with the densification of whispered voices added to the opening of a frequency filter.

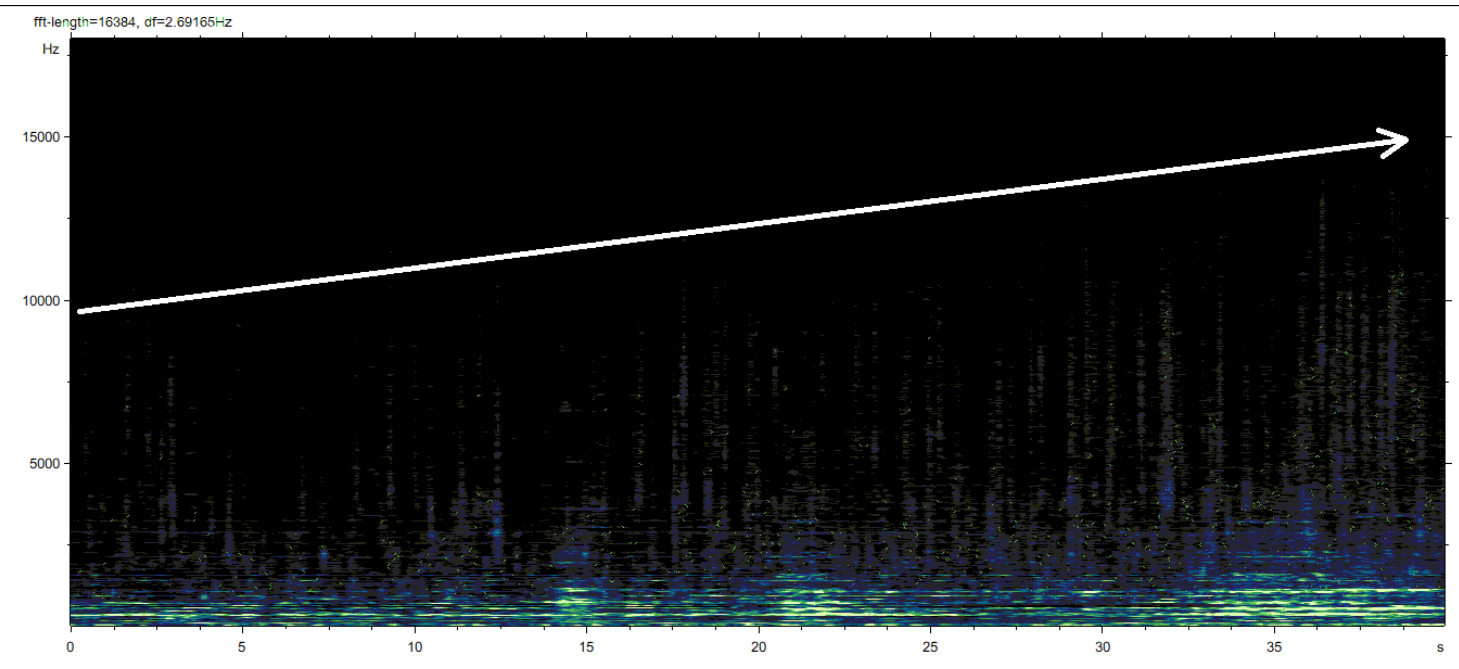

Figure 6: Spectrum Analysis (20Hz-18KHz), 1'50"-2'30" 

musical analysis of All Round Me by Russell Pinkston. MUSICA THEORICA. Salvador: TeMA, 201803, p. 68-96.

Figure 7 shows the final moments of All Round Me, when we can observe three spectro-morphological levels: (1) the recurrence of the low raps that we associate with the element $c$; (2) the grainy texture exerted by the wind chime that in Figure 7 is more evident between $5 \mathrm{KHz}$ and $10 \mathrm{KHz}$; and (3) six layers of a distinct high-pitched sound object (between $7,5 \mathrm{KHz}$ and $18 \mathrm{KHz}$ ), which has some temporal regularity, however is not easily audible.

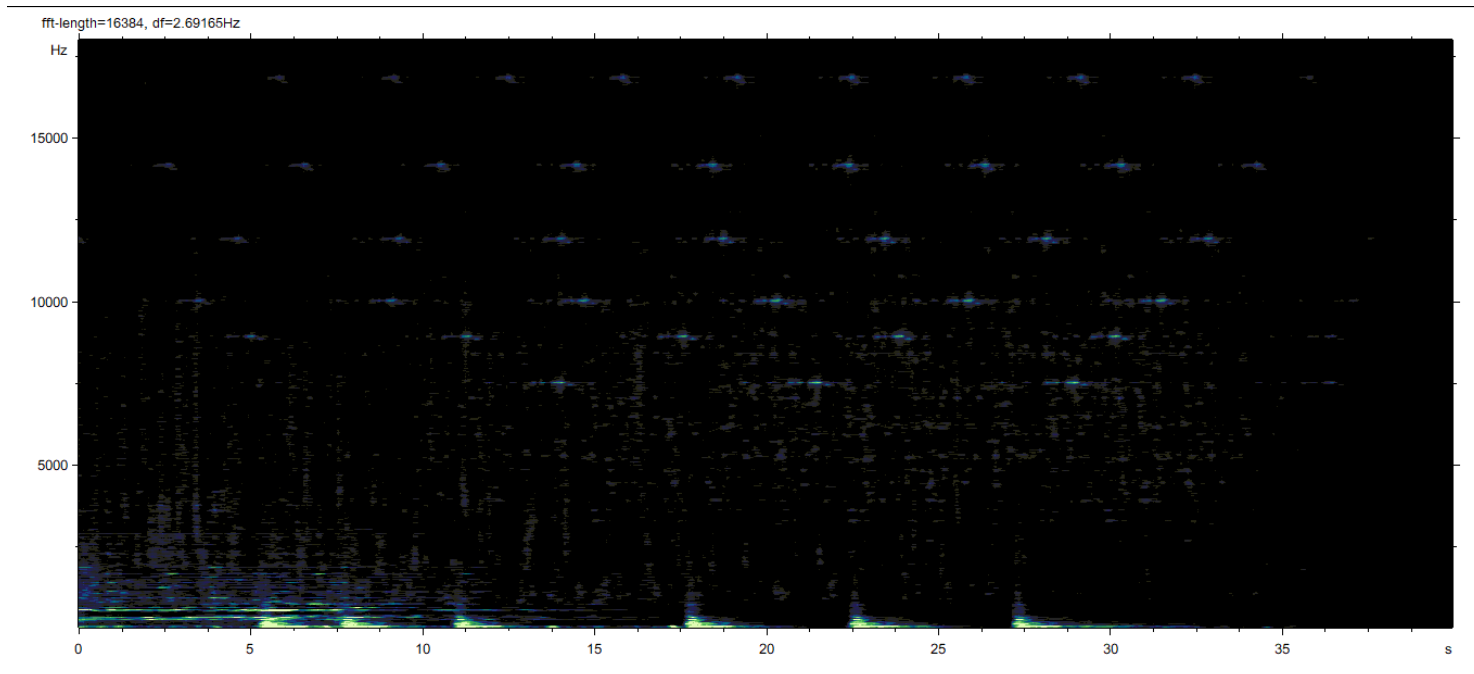

Figure 7: Spectrum Analysis (20Hz-18KHz), 2'50"'-3'33", 40 final secs of All Round Me

\section{2 - Cool Mist: 3'34" - 4'39"}

Cool Mist uses a single large unit of material throughout its length: whispered voice. Here is a similar movement to that observed in All Round Me, initially presenting the materials in isolation and gradually exploring the textural densification built with repeated overlap of these materials. As a systematization, we chose to separate the voices into four distinct groups for the analysis of Cool Mist, initially defined by their verbal content: "cool", "rain", "mist", and "all of a sudden", the latter used in split sentences (04'08" and $\left.04^{\prime} 40^{\prime \prime}\right)$. The graphical transcription illustrates the gradual presentation of vowel materials and their textural densification (see Figure 8).

The spectral analysis of this section (see Figure 9), however, shows us that a three-part division for the vowel materials of this section is efficient for spectral reasons. By understanding a phoneme as a "distinctive unit sound" (Coxhead 2006), which can be treated in the context of an electroacoustic composition as a single sound object, it is possible to explore the existence of not only one, but three distinct materials in Cool Mist. The words cool, rain and mist are formed by phonemes of different categories that gives them particular sonorities - $/ \mathrm{kul} /$, /rem/, and /mist/ in a phonetic transcription. The spectrum presented by the 

musical analysis of All Round Me by Russell Pinkston. MUSICA THEORICA. Salvador: TeMA, 201803, p. 68-96.

pronunciation of each of the three words also varies between three bands: the closed phoneme of cool produces a lower sound, whereas that of "rain" acts in the middle band of the spectrum; in turn, the apparent wheezing of "mist" highlights the word in the highest band of the spectrum. In Figure 9, it is possible to note these differences that are creatively explored by Pinkston. We quickly also note that the "rain" material ceases precisely at the midpoint of the section with the "all of a sudden" spinning. From this moment of discontinuity onwards only the "cool" and "mist" materials, that give the name to the section, remain superimposed.

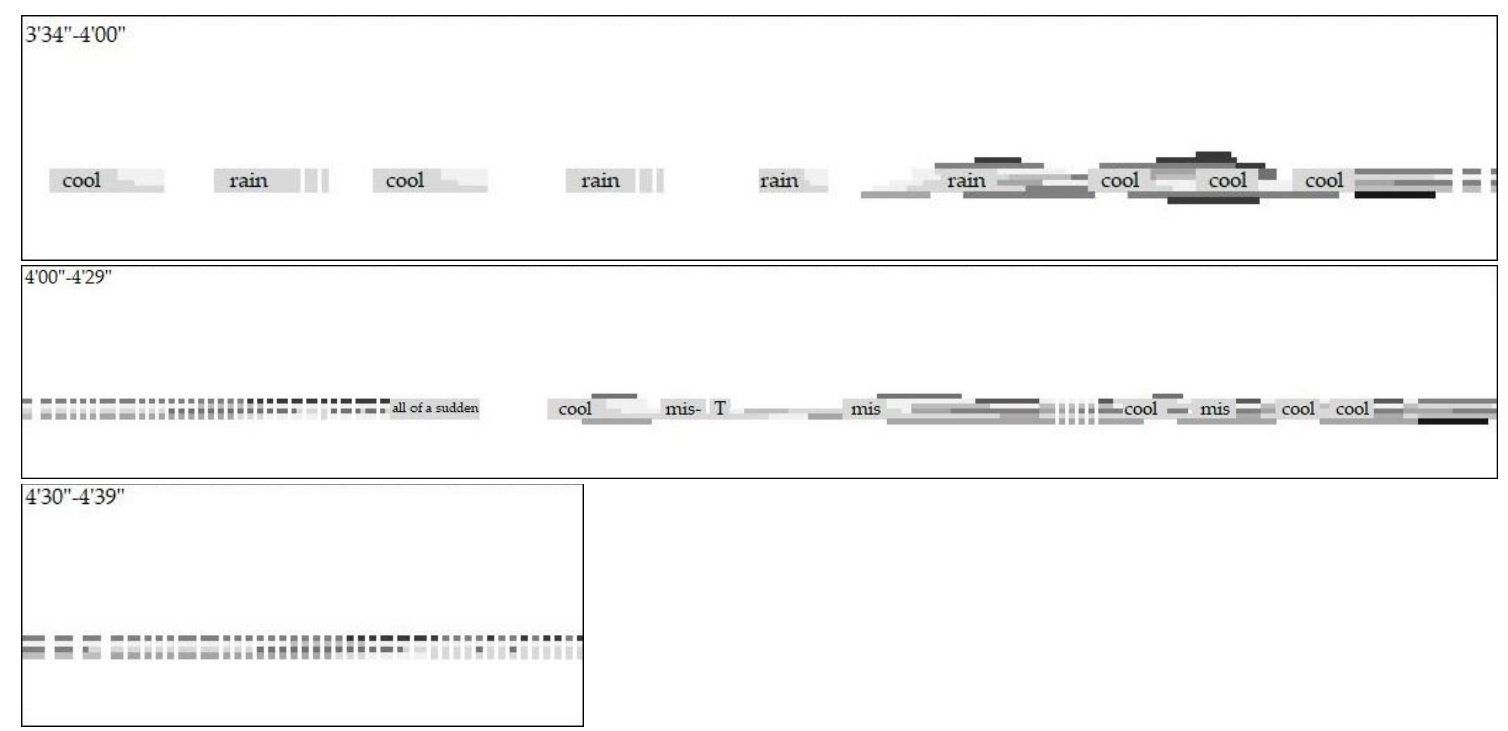

Figure 8: Graphical representation of structuring materials, 3'34"-4'39"

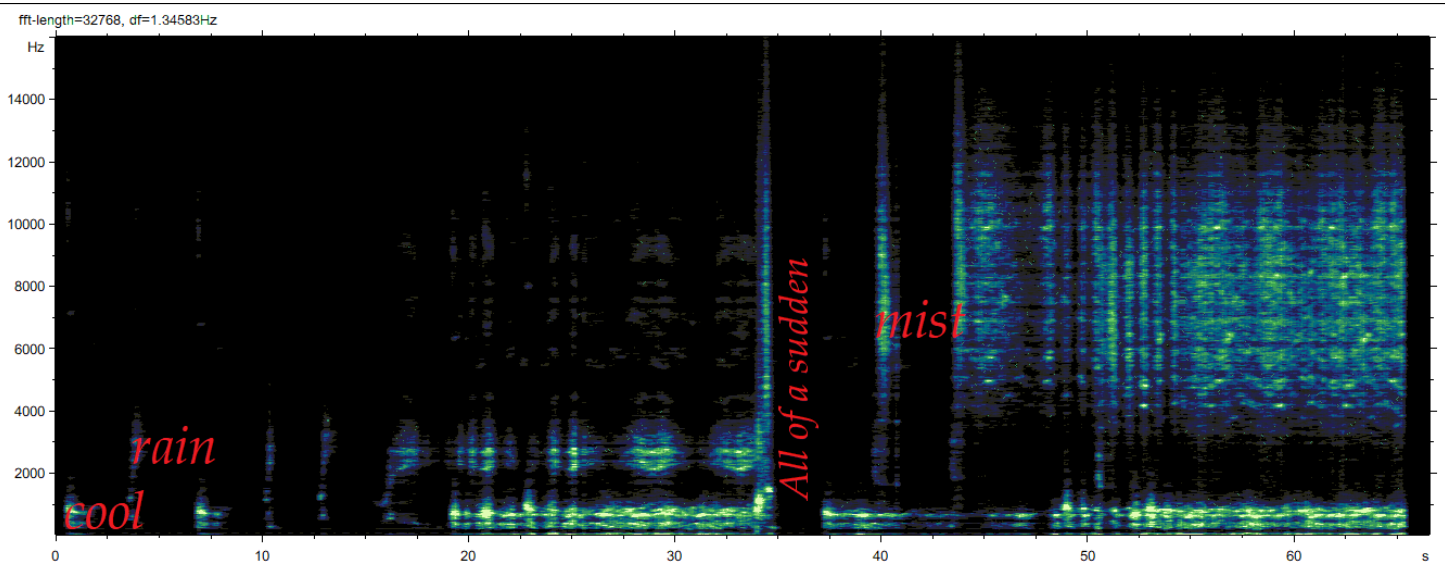

Figure 9: Spectrum Analysis (20Hz-16KHz), 3'34"- 4'39" 
GUMBOSKI, Leandro; ZOMER, Ana Letícia e MOREIRA, Adriana. 2018. Readings of a Work: a musical analysis of All Round Me by Russell Pinkston. MUSICA THEORICA. Salvador: TeMA, 201803, p. 68-96.

\section{3 - Transition: $4^{\prime} 39^{\prime \prime}-5^{\prime} 12^{\prime \prime}$}

In this analysis, we consider the section between $4^{\prime} 39^{\prime \prime}$ and $5^{\prime} 12^{\prime \prime}$ as a transition from Cool Mist to Sudden Rain, because it combines materials of these movements. Cool Mist is delimited by the voices, while Sudden Rain is markedly percussive. The appearance of percussive materials (in orange) is perceived in two moments of this transition: $4^{\prime} 58^{\prime \prime}$ and $5^{\prime} 03^{\prime \prime}$. We also noticed the reiteration of materials $c$ and $d$ of All Round Me (see Figure 10).

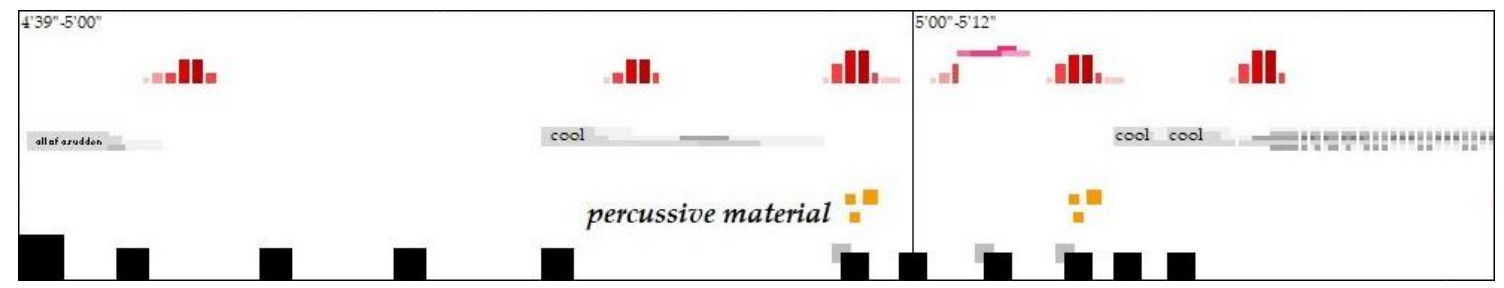

Figure 10: Graphical representation of structuring materials, $4^{\prime} 39^{\prime \prime}-5^{\prime} 12^{\prime \prime}$

\section{4 - Sudden Rain: 5'12"- 7'23"}

Of all the sections of the composition, in Sudden Rain the listener tends to infer the greatest sensation of movement, given the great amount of sound onsets in short time spans. Here we perceive a large number of transient elements of shorter duration, manifestly percussive - we understand them as "nodes", according to Smalley's (1986) theory. These percussive sound objects that, however, appear to be the result of synthesis and not recorded percussion, show traces of similarity with the material $c$ of the first movement of the composition. There is, therefore, a constant narrative that varies between moments of high density of material that symbolically brings the listener closer to these spiritual representations, and moments of less density that help to mark the beginning and the end of each section of the piece.

In the graphical representation, we observe the structure of the materials throughout this movement. We can notice the return of percussive materials in orange, presented previously in the transition, and the development of the voices presented in Cool Mist. The words cool, rain, mist, and all of a sudden, that can be clearly understood in the previous movement, are now transformed, becoming incomprehensible throughout this movement. From then on, we chose to place them below their sign representations, giving greater emphasis to the sound material (see Figure 11). 

musical analysis of All Round Me by Russell Pinkston. MUSICA THEORICA. Salvador: TeMA, 201803, p. 68-96.

The rhythmic aspect of Sudden Rain can be considered a metaphor of the rain sonority. There are different sound levels in the noise of rain, although this is an aspect that varies according to its own volume (Hopkins 2006). In practical terms, different drip planes, even with identifiable patterns, are superimposed on many others with different time-patterns and spectral characteristics. On the whole, what you hear is texture. In Sudden Rain, parametric reasons, especially timbre and pitch, make these different planes are easily identifiable by the listener. There is not, however, enough overlap to produce an amorphous complex such as the sound of proper rain. The listener recognizes the planes distinctly but the randomness within each plane, makes it impossible to recognize a clear pattern. Therefore, the listener cannot realize any projectable recurrence or repetition.

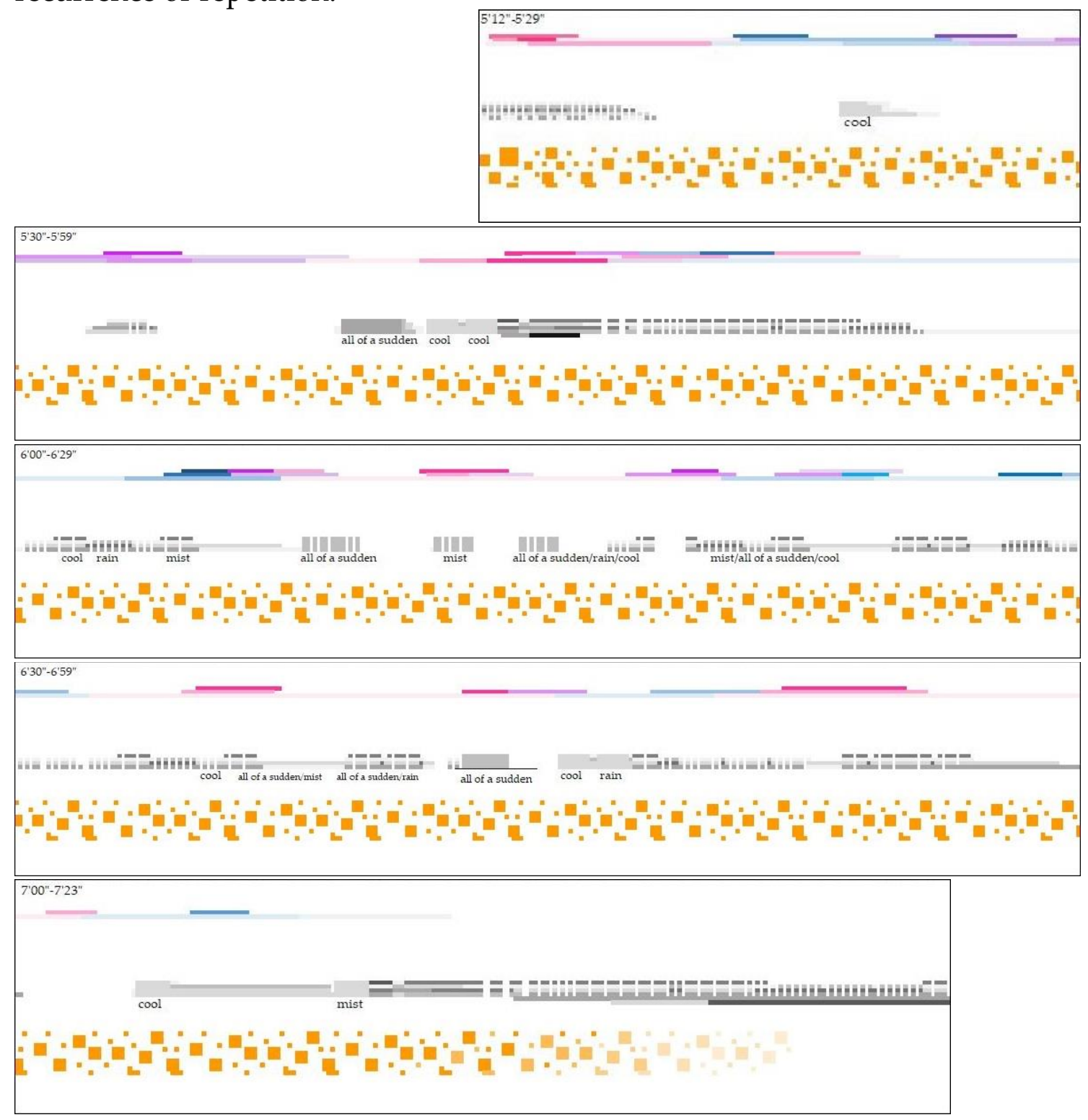

Figure 11: Graphical representation of structuring materials, 5'12"-7'23" 
GUMBOSKI, Leandro; ZOMER, Ana Letícia e MOREIRA, Adriana. 2018. Readings of a Work: a musical analysis of All Round Me by Russell Pinkston. MUSICA THEORICA. Salvador: TeMA, 201803, p. 68-96.

Figure 12 shows that a narrower region of the frequency spectrum was used in Sudden Rain when compared to the other movements of the composition. There is little information above $3 \mathrm{KHz}$, which corroborates the sensation of synthesis or sound manipulation of percussion, given the suppression of typical harmonics we hear on most drum sounds. The listener's focus is on the low spectrum of these recurring percussive strokes, what seems to be purposeful: the last vowel materials section, operating freely in the highest band of the spectrum, is repeated by the extension of Sudden Rain. From the formal point of view, this section sounds like a development of the previous one. In an analysis of the "patterns of patterns" (Thoresen and Hedman 2007) all three initial sections of All Round Me sound cohesive and organic, a whole that is only broken by the discontinuity between the first two sections, but it continues to sound like a symbolic continuum of closeness and remoteness of spirit-manifestations. This continuum, which is not merely symbolic but rather spectro-morphological, is broken by the next section of the composition, Tree Colors Darkening.

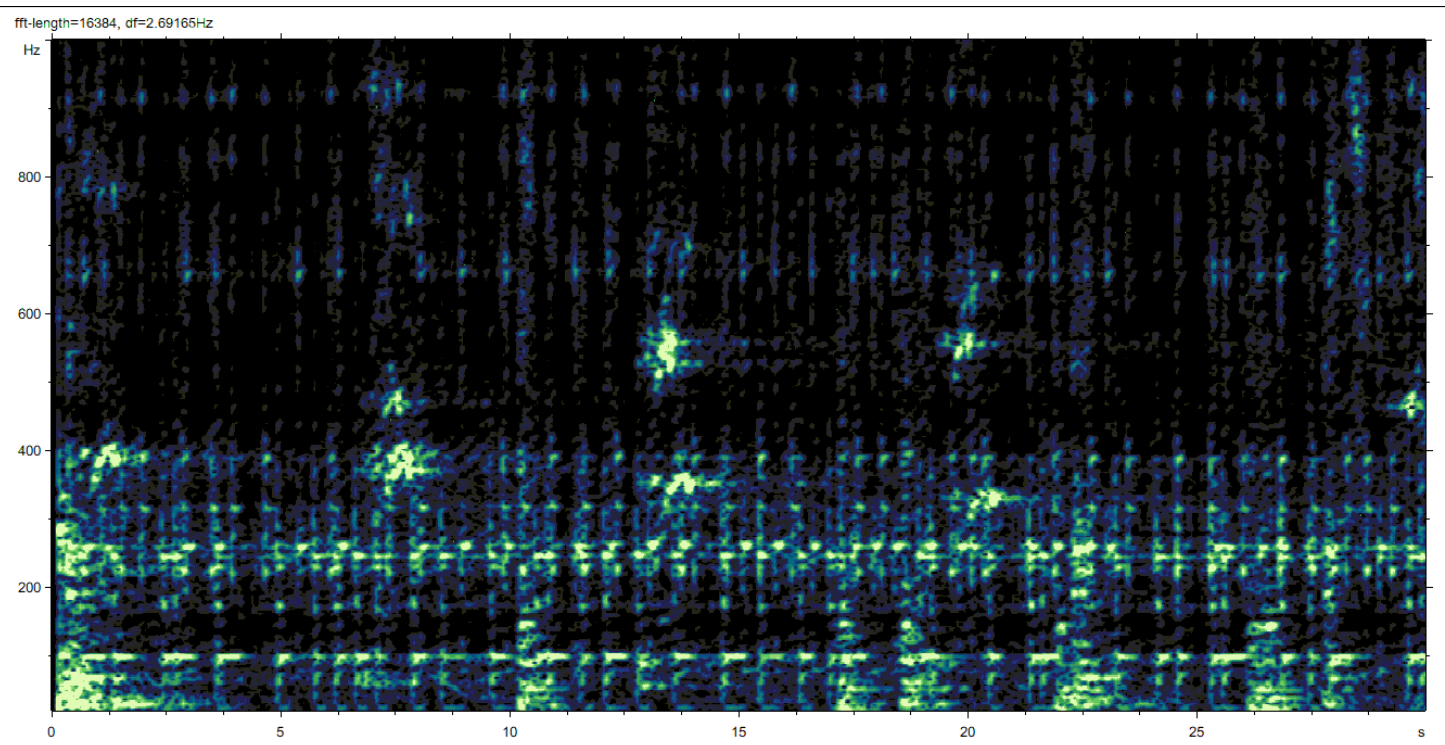

Figure 12: Spectrum Analysis (20Hz-1KHz), 5'12"'-5'42", 30 first seconds of Sudden Rain

\section{5 - Tree Colors Darkening: 7'24"-10'15"}

Of all the movements of All Round Me, this one uses materials that better approaches the "note" concept of Smalley's (1986) tripartite "note-node-noise" model. Based on the principle of metaphorical description, we refer to this material as "atmosphere". We use this term because the material in question does not represent spirit-manifestations in themselves, nor is it related to physical 

musical analysis of All Round Me by Russell Pinkston. MUSICA THEORICA. Salvador: TeMA, 201803, p. 68-96.

objects, such as the wind chime. This is a unique material that seems to be related to the creation of a "spiritual atmosphere," in an apparently non-diegetic fashion. By way of description, the material sounds like a synthesized set of strings instruments. The entire movement sounds highly textural as it forms a chain of upward and overlapping gestures that are arranged as an octatonic scale. There is, therefore, great contrast with respect to the previous section: from the composition's largest movement, we move on to the smallest movement. This type of "graduated continuant" (Smalley 1997) can be visualized in Figure 13, where the absence of moments of silence is observed: before the end of each note there is the beginning of others. This elision process guarantees textural continuity to the movement and omits to the listener repetition patterns that seem to occur throughout the process.

These patterns of repetition, however, fail to establish marks of a temporal linear discourse. On the contrary, the texture of Tree Colors Darkening presents itself as a sound representation of an impossible object, such as the Penrose stairs. The principle of something endless, as well as that of something impossible in an apparent reality, can be taken as a symbolic link to the narrative of the piece. Here the listener does not experience representations of spirit-manifestations, but of the very context of the existence of its sources. The listener associates it with diverse sensations, such as anguish, affliction, suspense, for example, but does not relate to physical actions of real objects or elements, as it happens throughout the composition.

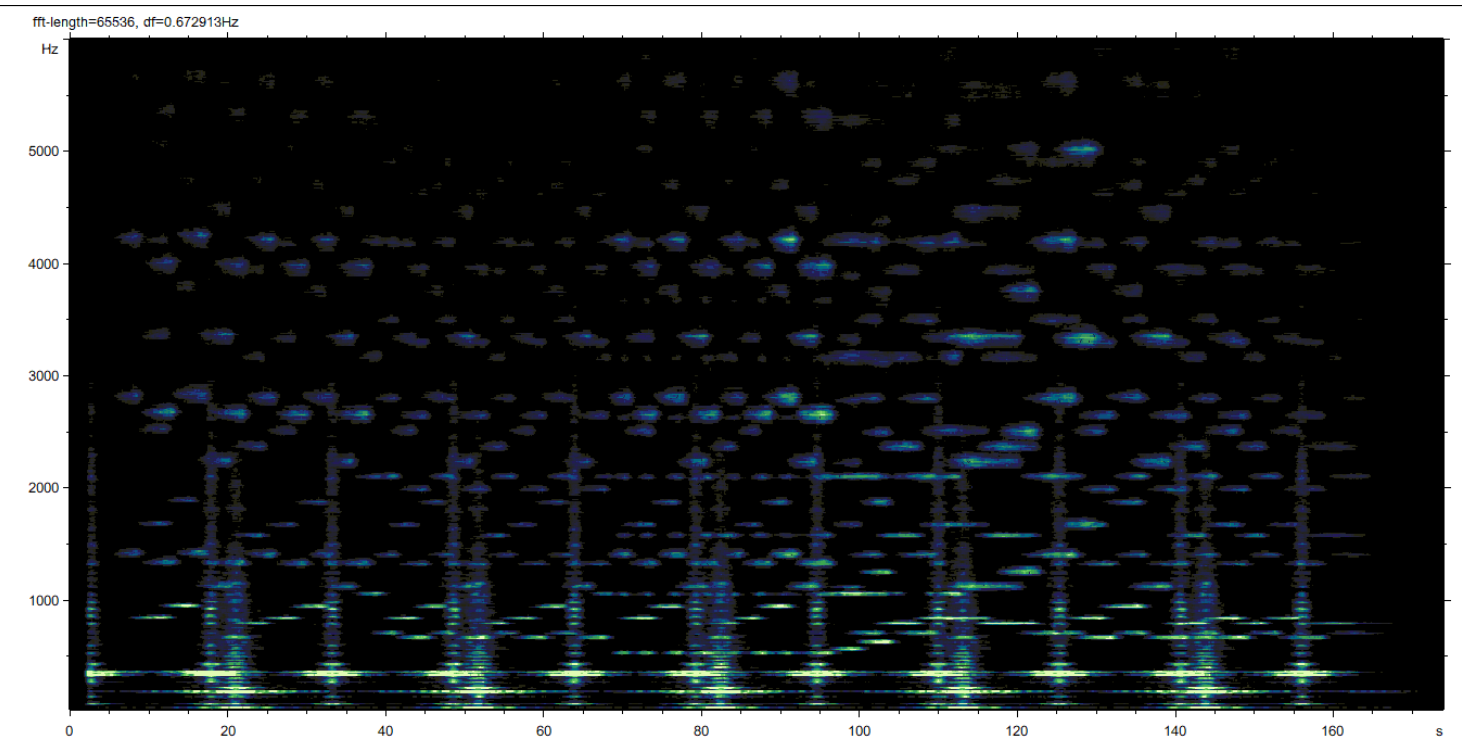

Figure 13: Spectrum Analysis (20Hz-6KHz), 7'24"-10'15" 

musical analysis of All Round Me by Russell Pinkston. MUSICA THEORICA. Salvador: TeMA, 201803, p. 68-96.

\section{6 - The Monastery: 10'16"- 12'20"}

The last two sections of All Round Me are marked by the entrance of a new percussive material: mbira. Quite apart from a metaphorical description, as we have done in other sections (with the exception of the "wind chime" sound material), this seems to be a purposeful symbolic reference. The mbira is a musical instrument found in various cultures of the African continent. According to Berliner (1981), the mbira is directly associated with the way of being of the Shona (Zimbabwe). This instrument, in projecting its sound through the air, represents a means of connection with the world of its dead ancestors. The Shona believe that events in the living world are determined by the world of the dead, hence the need for spiritual connection, which is only possible through the sonority of this instrument (Berliner 1981).

The Monastery, as well as the opening movements of All Round Me, presents dynamics in crescendo until a sudden silence in $12^{\prime} 19^{\prime \prime}$ - a discontinuity that marks the end of the section and the beginning of the next one. The texture of the movement is mainly composed of the mbira and voices. It corroborates with the gradual increase of loudness and exhibits a progressive development of densification. Here the material "voices", however, has a significantly modified morphology by chorus-like processing (Kahlin and Ternström 1999) with very short intervals between the repetitions. Although we identify sound objects, the same does not happen - as in the first movement of the composition - with its verbal content due to the before mentioned transfiguration.

It should be highlighted that the reference made to the mbira implies that melodic content prevails in the two closing sections of the piece. The mbira in The Monastery freely alternates between notes C, E flat and G (with a rapid passage on A flat), defining a harmony close to $\mathrm{C}$ minor. This complex combination of elements of the "note" type - according to the tripartite model of Smalley (1997) - with others that move away from this axis towards the "node" or "noise" types, is another factor that correlate this section with the initial section All Round Me. In both, the tonal content relates to the minor mode, suggesting introspection, what correlates with the title of the composition.

In Figure 14, we depict the structural materials throughout this movement. The blue circles mark the input of mbira sounds that gradually manifest themselves in odd sound groupings with increasing constancy from $11^{\prime} 23^{\prime \prime}$ on, just like the reiteration of the voices, in gray. 
GUMBOSKI, Leandro; ZOMER, Ana Letícia e MOREIRA, Adriana. 2018. Readings of a Work: a musical analysis of All Round Me by Russell Pinkston. MUSICA THEORICA. Salvador: TeMA, 201803, p. 68-96.

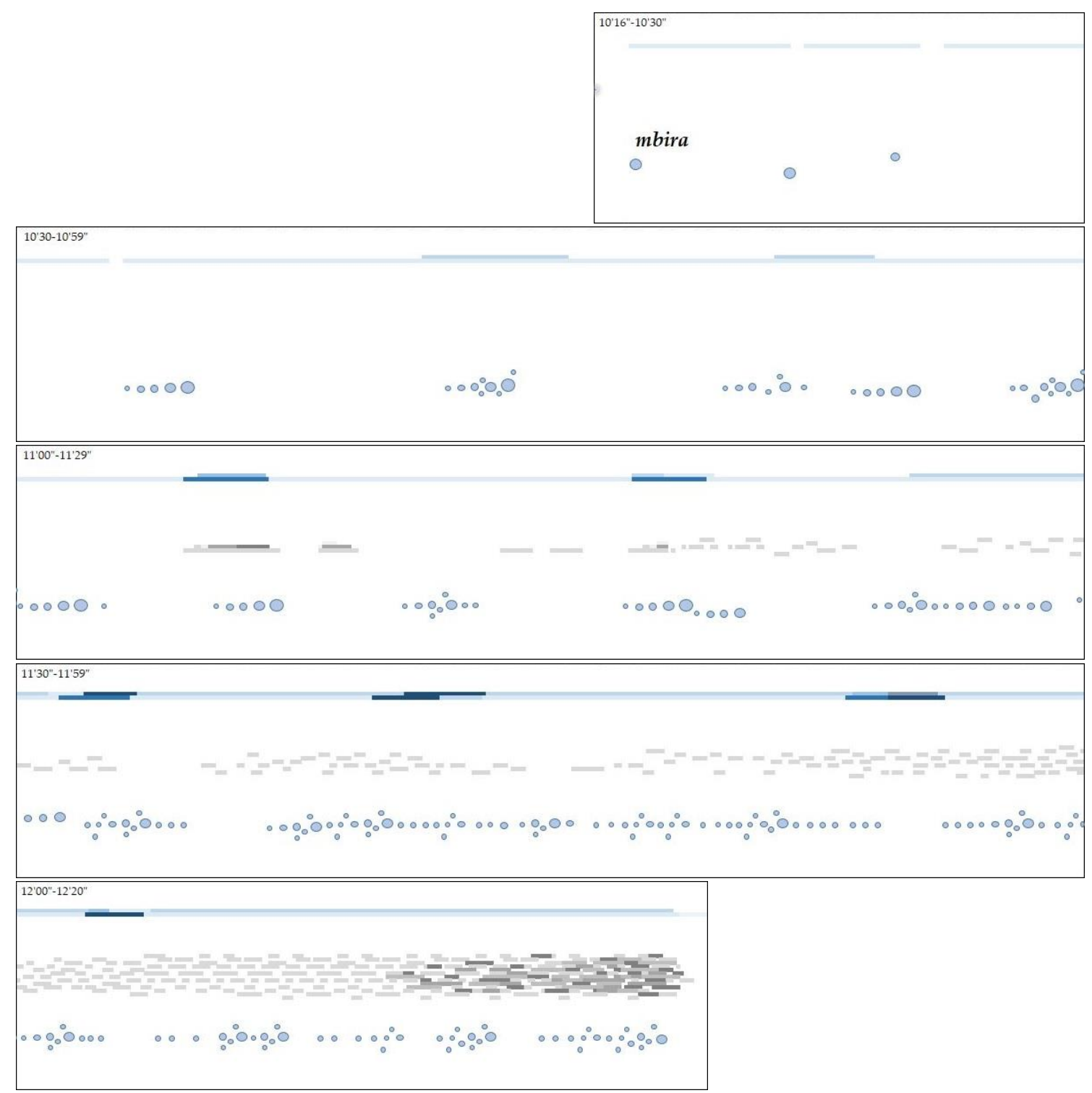

Figure 14: Graphical representation of structuring materials, 10'16"- $12^{\prime} 20^{\prime \prime}$

\section{7 - A Bonging of Bells: 12'20 - 14'40"}

The movement that closes All Round Me is also the climax of the composition with respect to dynamics and texture. In the complex of sound objects disputing space in the spectral plane, the listener can perceive the recapitulation of materials - especially $a, b, c$, and $e$ - of the first section of the composition. The material $c$, unlike in the movement All Round Me, is presented at regular intervals of $4^{\prime \prime}$ and $5^{\prime \prime}$ (after 13'25"). In turn, the recapitulation of material $b$ favors the maintenance of a tonal content, now under $\mathrm{B}$ flat minor. This same tonal plane is maintained by the mbira that cuts the whole movement, remaining as the only element at the end of the composition. The "atmosphere" 

musical analysis of All Round Me by Russell Pinkston. MUSICA THEORICA. Salvador: TeMA, 201803, p. 68-96.

timbre material of the previous section is taken up now into a lower band by developing a descending trajectory, typical of a bass line. In the graphical representation, we can see the structuring of the predominant materials (see Figure 15).

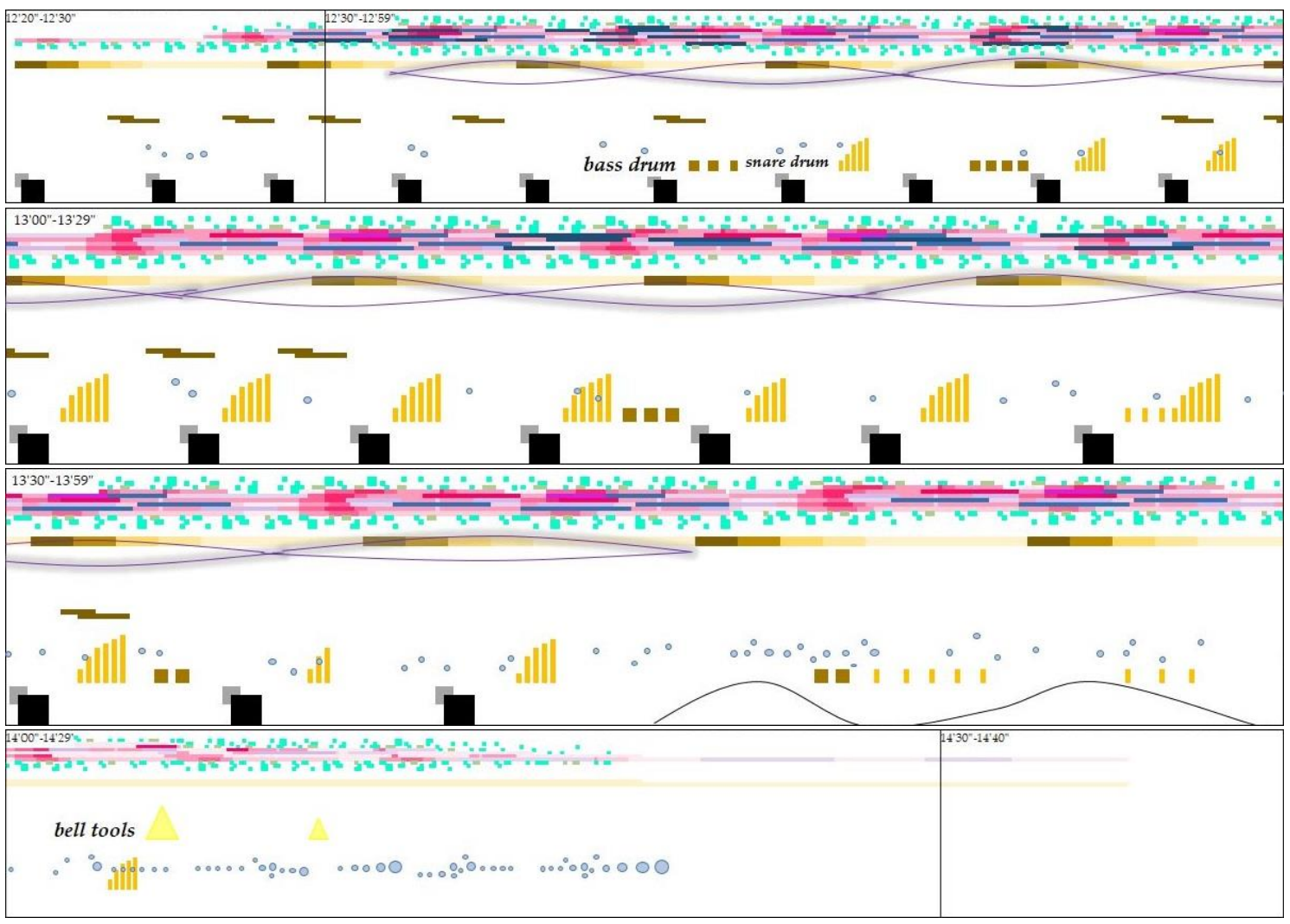

Figure 15: Graphical representation of structuring materials, 12'20"' - 14'40"

In this complex process of overlapping materials, a new percussive gesture is inserted at $12^{\prime} 46^{\prime \prime}$, marking the whole movement with lofty drum rolls. The reference to their source is direct: snare drum (in small orange columns) and bass drum (brown squares). The listener tends to attribute double meaning to such sound gestures. If, on the one hand, we recognize the use of percussion as a proper element for climatic sections, on the other hand, the gesture itself - snare drum roll followed by accentuated bass drum notes - is characteristic of military or warlike contexts in which the tension between life and death is immanent. At the end of the section, there are two bell tolls, the first at $14^{\prime} 05^{\prime \prime}$ and the second at $14^{\prime} 10^{\prime \prime}$, which strengthen the aforementioned reference to sound sources. These elements are set in opposition due the absence of the whispered voice material as an expressive spirit-manifestation, i.e., they are distant from the listener.

Without the presence of whispered voices and the occurrence of "sound raps" such as spirit-manifestations at the beginning of the section, The Bonging of 
Bells seems to suggest narratively a departure from the world of the dead - the oblivion of the recurrent quotes of spiritual representations. When closing in $14^{\prime} 40^{\prime \prime}$, we have a confirmation of this premise: 1440 is the number of minutes in a day, which becomes a symbolic representation of life, especially in chronologically organized societies like the Modern West (Aguiar 2011).

\section{3 - Final considerations and conclusions}

Russell Pinkston's All Round Me is a sui generis electroacoustic work for several reasons. From a structural point of view, the listener must recognize the presence of elements related to traditional instrumental music, even if these are explored in an unorthodox way. There is also occasional tonal-melodic content expressed mainly by the material $b$ in the initial and closing sections of the piece, by the mbira material in the last two movements, and by the entire texture of Tree Colors Darkening. Temporal structures also play an important role. There are very exact proportions in various parts of the composition, whether in terms of the chronometric timing of the beginning and ending of sections (that can be interpreted as meaningful, as discussed above) or in the temporal structure of the sound objects arranged in each of these sections. In this sense, the more rhythmic sound of Sudden Rain stands out. However, the traditional elements are not responsible for delimiting the formal structure recognition.

From the spectro-morphological point of view, we highlight that Pinkston's composition transits between the various categories theorized by Smalley $(1986,1997)$. More than a combination of elements from different categories, we notice, at many moments in the piece, processes of transmutation of categories: from gesture to texture, from note to noise. These processes generate contrasts that are striking to the listener, besides determinants of the formal structure and of the narrative meaning of the composition.

We follow Coelho de Souza's (2013, p. 29) point of view that alternations of topical meanings in a composition induce the ear to recognize marked differences between the sections of musical discourse. In the case of an electroacoustic composition, we point out that the six different sections of All Round Me can be identified by distinguishing material categories: sound objects, agglomerates of objects, transmutations of objects, gestures and textures. All of them deal with a dual level of interpretation: their spectro-morphology and the meaning attributed by contextual listening, or in a broad sense, by what we might call musical topoi. 

musical analysis of All Round Me by Russell Pinkston. MUSICA THEORICA. Salvador: TeMA, 201803, p. 68-96.

The contrast effect produced by musical topoi can be used to confer a formal design for a genre in which traditional syntactic means, such as harmonies or serial processes, can no longer be employed (Coelho de Souza 2013, p. 34).

We believe that the clear definition of large sections in All Round Me is also due to a practical aspect: the composer needs to delimit tableux for a ballet piece. However, we try to demonstrate throughout the analysis that there is no misrepresentation of the musical discourse, but, on the contrary, there is the development of contrasts that keep the listener attention active and attentive to the compositional narrative. This feature provides us with a basis for understanding Pinkston's piece not only as an acousmatic work in which aural attention is directed only - or more intensely - to spectro-morphological details, i.e., it is reduced to the perception of the sounds themselves. From such sound characteristics, the listener may recognize the stages of the ongoing narrative based on the tension between life and death - closeness and remoteness of spiritmanifestations. The presence of direct quotes from sound objects such as the wind chime and the mbira reinforce this perspective, since the attention of the listener is not directed solely to the qualities of these sounds, but also to the real objects that produce them. The main character of this narrative, therefore, is the listener himself - the subject in first person.

There is, in the aesthetic experience of All Round Me, a process of materialization of what is immaterial. It is not a direct reference to palpable recognizable objects (e.g., a train), except for the wind chime and the mbira (diegetic narrative agents) as well as the bass drum, snare drum, and bells that fill the closing track of the piece, but it is a reference to socially constructed archetypical sonorities (Almén 2003, 2008). If, on the one hand, we intend a technical and metaphorical description of the spectro-morphological characteristics of the sounds of spirit-manifestations, such as that of Kardec (1986 [1861]), on the other hand, the interference and contribution of other means, such as cinematographic language (Cf. Fowkes 1998, Leeder 2015), in the construction of these archetypes, is very important. As an observation, we would like to point out that the definition of most of the characteristics of the idea of spiritmanifestations began in the middle of the nineteenth century, for various reasons. We could list: (1) the founding of the Spiritist Doctrine itself, by Kardec; (2) the emergence of photography and the propagation of the possibility to inscribe spirits - in reality, the technique of printing by superposition of plates (Newhall 1982), and (3) the Victorian Era, which produced a number of stories and novels around ghostly and spiritual themes (Mcleod 2007). Thus, we note that whispered voices, for example, may contain multiple meanings, but the context in which Pinkston's composition presents itself and "extra-musical" cues such as the title of the piece and its sections, can lead the listener to meanings 

musical analysis of All Round Me by Russell Pinkston. MUSICA THEORICA. Salvador: TeMA, 201803, p. 68-96.

such as those presented here. In addition, the element "whispered voice", as a spiritual manifestation closer to the listener in the composition, is treated largely only in its spectro-morphological aspects: it contributes to the compositional narrative by the identification of its source - spirit - and not by its verbal content.

"One of the fascinating possibilities offered by electroacoustic music technology is the invention of sound spaces that could not exist in real physical nature" (Coelho de Souza 2013, p. 32). In All Round Me, we can apply the term "spatialized music", that is, music that gives importance to the behavior of materials by means of the positioning, movement and ambiance of sound sources (Thomaz 2007, p. 23). For Smalley, space plays a fundamental role in the structure of listening, insofar as it is capable of being "a means of enhancing the sound proprieties inherent in spectro-morphologies and structural relations" (Smalley 1991, p. 123). His approach presents a series of space categories, from the "composite space" (the space idealized by the composer) to the "space of listening" (the space where the work is experienced). Chion (1988) also conceives the articulation of space in electroacoustic music through two levels: internal and external. The internal refers to the intrinsic spatiality of the spectro-morphology, while the extrinsic refers to the way in which the sound is diffused in space during the performance (Lima 2013, p. 16).

Different manipulation strategies of the sound envelope can generate different interpretations of sound sources locations (front/background, left/right), sound plane recognition (near/distant) and construction of virtual acoustic spaces (large/small, dry/reverberant) (Campesato 2007, p. 134). Pinkston, therefore, creates a simulated space through sound data connected to parameters of source location and room size, generating an auditory sensation of spatiality. "Using dynamic combinations of panning, alteration of dry-reverb balance, change in amplitude, and filtering, one can give the impression that some items in the soundstage are moving and others not" (Lennox 2009, p. 263).

Throughout the piece, we notice that the sound materials seem to be in movement, with different speeds and in varied locations, according to the space determined by the composer. We observe a series of combinations of sounds, with different spatial behaviors and trajectories. The circular movement in the clockwise and counterclockwise directions, sometimes superimposed on two and three layers of the spatial plane is, in our view, the most prominent movement in the piece. This sound behavior will dialogue with the imaginary visual associations suggested by the narrative and with the titles of the work. A dialogue between sounds, mental images and space is then established. Despite this complex conceptual setup, Pinkston composes the piece for stereo format: the audio reproduction system that uses only two channels (left and right).

We believe, therefore, to have contemplated, in general terms, essential aspects of the narrative of the piece. Almén points out that 
GUMBOSKI, Leandro; ZOMER, Ana Letícia e MOREIRA, Adriana. 2018. Readings of a Work: a musical analysis of All Round Me by Russell Pinkston. MUSICA THEORICA. Salvador: TeMA, 201803, p. 68-96.

an analysis of musical narrative must take into account: 1) an assessment of the semantic characteristics of musical elements, both in isolation and in context; 2) an understanding of how these elements mutually influence and mutually define each other as they succeed one another in time; and 3) an awareness of the cumulative, global effect of these relationships in terms of the opposition "order vs. transgression" and the logically possible outcomes of such an opposition, or narrative archetypes (Almén 2003, p.12).

So, with regard to the consequences of the narrative genre, given by the opposition of elements that assume the "order" function of those who exercise the "transgression", we understand, based on Almén (2003, 2008), that the state of "order" is usually thematic order, while the "transgression" implies contrast of any kind. In this way, we understand that in All Round Me the "order" is in materials representative of spirit-manifestations - as in the initial gesture $a-b / c-d$. The contrasting "transgression" is performed by those elements representative of life - such as the wind chime, the mbira, and the snare drum. The whole composition sounds like a continuum of contrasts between all these elements. The discourse, therefore, seems to move from life (of the listener himself) surrounded by death, but ending with life prevailing. The emphasis therefore is on the meaning of "victory" - triumphantly announced by the gestures of snare drum and bass drum, but also accomplished by the mbira sound, finishing in 14'40". Nevertheless, the descendant movement in A Bonging of Bells, made by the "atmosphere" material (low-pitched, like a bass line), can be read by the listener as a symbol of "defeat". The narrative, starting with elements of "death" and ending with those of "life", would corroborate this reading.

In either of the two narrative plots described above, the victorious element is "life", while the defeated is "death". Based on Almén's theory $(2003,2008)$ of four narrative archetypes (Romance, Tragedy, Irony and Comedy), we should conclude that the narrative genre of All Round Me is either Romance - victory of order (life) over transgression (death) or Irony/Satire - defeat of order (life) by transgression (death). In our interpretation, expressive and energetic aspects lead us more consistently to the first hypothesis, requiring a quite sceptic standpoint to adhere to the second possibility.

The spatiality of the composition, highly dynamic, is another factor that contributes to a narrative reading, as represented in Figure 16. 

musical analysis of All Round Me by Russell Pinkston. MUSICA THEORICA. Salvador: TeMA, 201803, p. 68-96.

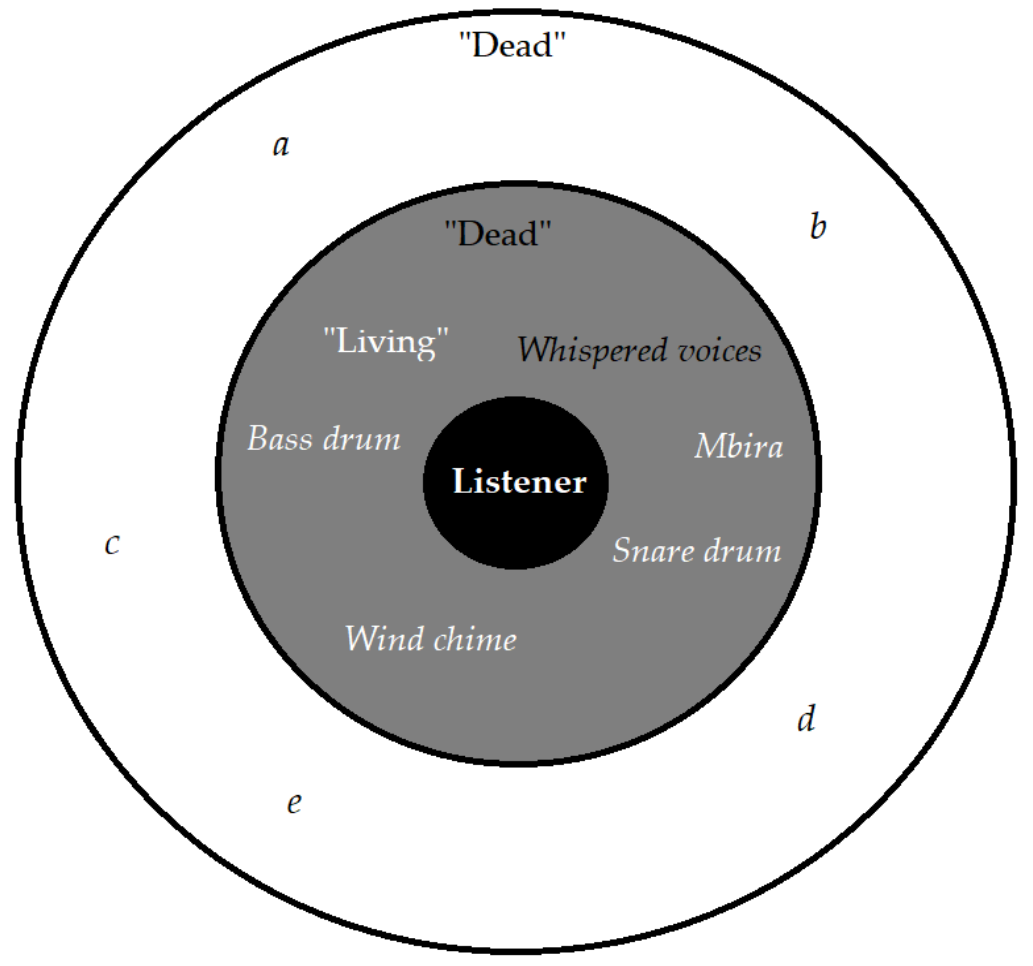

Figure 16: Representation of the positioning of materials in the space in All Round Me

In the previous illustration, the gray space, close to the listener, is shared by sonorities representative of life - attracted by the listener as the main living elements of the narrative - and whispered voices, as a manifestation of death spirits that are closest to the listener. The blank space is filled by all those spiritmanifestations described throughout the article, of which the materials $a, b, c, d$, $e$ stand out. If, on the one hand, the proportion attributed by the listener to these meanings depends on cultural factors, such as religious orientation, on the other hand, we recognize that All Round Me perfectly fulfills the aesthetic goal of representing life surrounded by spirits of death (Pinkston 2018), using paradigmatic techniques of electroacoustic composition.

\section{References}

1. Aguiar, Neuma. 2011. Mudanças no uso tempo na sociedade brasileira. Revista de Ciências Sociais, no 34, p. 73-106.

2. Almén, Byron. 2003. Narrative Archetypes: A Critique, Theory, and Method of Narrative Analysis. Journal of Music Theory 47(1), p. 1-39. 
GUMBOSKI, Leandro; ZOMER, Ana Letícia e MOREIRA, Adriana. 2018. Readings of a Work: a musical analysis of All Round Me by Russell Pinkston. MUSICA THEORICA. Salvador: TeMA, 201803, p. 68-96.

3. 2008. A Theory of Musical Narrative. Bloomington: Indiana University Press.

4. Berliner, Paul F. 1981. The Soul of Mbira: Music and Traditions of the Shona People of Zimbabwe. $2^{\text {nd }}$ ed. Chicago: University of Chicago Press.

5. Campesato, Lílian. 2007. Arte sonora: Metamorfose das Musas. Master Thesis, University of São Paulo.

6. Chion, Michel. 1983. Guide des objets sonores: Pierre Schaeffer et la recherche musicale. Paris: Buchet/Chastel.

7. Coelho de Souza, Rodolfo. 2013. Abstração e representação na música eletroacústica. Revista Vórtex, no 1, p. 23-35.

8. Coull, Rosalyn Victoria. 2015. Portfolio of Compositions: Emotion, Meaning $\mathcal{E}$ Narrative in Electroacoustic Music. Doctoral Dissertation, College of Arts and Law, The University of Birmingham.

9. Couprie, Pierre. 2004. Graphical representation: an analytical and publication tool for electroacoustic music. Organised Sound, v. 9, no 1, p. 109-113.

10. Coxhead, Peter. 2006. Natural Processing \& Applications: Phones and Phonemes. Edgbaston: University of Birmingham. Available at: $<$ http://www.cs.bham.ac.uk/ pxc/nlp/index.html>.

11. Fenerich, Alexandre Sperandéo. 2005. Questões da representação na música eletroacústica. Master Thesis. Universidade Federal do Rio de Janeiro.

12. Ferraz, Silvio. 2008. Duas peças de Rodolfo Caesar: Tinnitus (2004) e Bioacústica (2005). Música Hodie, v. 8, no 1, p. 87-98.

13. 2007. Notas do caderno amarelo: a paixão do rascunho. LivreDocente Dissertation. Universidade de Campinas.

14. Fowkes, Katherine. 1998. Giving up the Ghost: Spirits, Ghosts, and Angels in Mainstream Comedy Films. Detroit: Wayne State University Press.

15. Garcia, Denise Hortência Lopes. 2008. Introdução à Pedra de Rodolfo Caesar: Leituras de uma obra. Anais do III Seminário de Música, Ciência e Tecnologia, Universidade de São Paulo, p. 80-96. 
GUMBOSKI, Leandro; ZOMER, Ana Letícia e MOREIRA, Adriana. 2018. Readings of a Work: a musical analysis of All Round Me by Russell Pinkston. MUSICA THEORICA. Salvador: TeMA, 201803, p. 68-96.

16. . 2001. Modelos Perceptivos na Música Eletroacústica. Anais do XIII Encontro Nacional da ANPPOM, Belo Horizonte, p. 155-169.

17. . 1998. Modelos perceptivos na música eletroacústica. Doctoral Dissertation, Pontifícia Universidade Católica de São Paulo.

18. Giomi, Francesco; Ligabue, Marco. 1998. Understanding electroacoustic music: analysis of narrative strategies in six early compositions. Organised Sound 3(1), p. 45-49.

19. Gubernikoff, Carole. 2007. Metodologias de Análise Musical para Música Eletroacústica. Revista eletrônica de musicologia, v. XI. Available at: $<$ http://www.rem.ufpr.br/_REM/REMv11/10/10-carole-analise.html>.

20. Hopkins, C. 2006. Rain noise from glazed and lightweight roofing. BRE Information Paper, IP 2/6.

Available at: $<$ https://www.bre.co.uk $>$.

21. Kahlin, Daniel; Ternström, Sten. 1999. The Chorus Effect Revisited: Experiments in Frequency-Domain Analysis and Simulation of Ensemble Sounds. IEEE 99, p. 75-80.

22. Kardec, Allan. 1986. The Mediums' Book. Anna Blackwell (trad.). $2^{\text {nd }}$ ed. Rio de Janeiro: Federação Espírita Brasileira.

23. Leeder, Murray (Ed.). 2015. Cinematic Ghosts: Haunting and Spectrality from Silent Cinema and to the Digital Era. New York: Bloomsbury Academic.

24. Lennox, Peter. 2009. Spatialization and Computer Music. In: Dean, Roger T. (Ed.). The Oxford Handbook of Computer Music. New York: Oxford University Press.

25. Lima, Gabriel Rimoldi. 2013. Modelagem interativa aplicada à síntese e espacialização no domínio microtemporal. Master Thesis, Universidade Estadual de Campinas.

26. Magliocco, Sabina. 2004. Witching Culture: Folklore and Neo-Paganism in America. Philadelphia: University of Pennsylvania Press. 
GUMBOSKI, Leandro; ZOMER, Ana Letícia e MOREIRA, Adriana. 2018. Readings of a Work: a musical analysis of All Round Me by Russell Pinkston. MUSICA THEORICA. Salvador: TeMA, 201803, p. 68-96.

27. Mcleod, Melissa Kendall. 2007. Sound of Terror: Hearing Ghosts in Victorian Fiction. Doctoral Dissertation, Georgia State University.

28. Newhall, Beaumont. 1982. The History of Photography: From 1839 to the Present. $5^{\text {th }}$ ed. New York: The Museum of Modern Art.

29. Pinkston, Russel. 2005. All Round Me. Russell Pinkston - Four Electroacoustic Dance Suites. CDCM Computer Music Series, Vol. 34. Centaur Records, CRC 2764.

30. Pinkston, Russell. 2018. All Round Me - Program Note. Russell Pinkston Web Site. Available at: <http://www.russellpinkston.com/?portfolio=all-round-me>.

31. Smalley, Dennis. 1986. Spectro-morphology and structuring processes. In: Emmerson, Simon (org.). 1986. The language of electroacoustic music, p. 61-93. New York: Harwood Academic.

32. 1997. Spectro-morphology: explaining sound-shapes. Organised Sound 2(2), p. 107-126.

33. Svidzinski, João Estivalet; Bonardi, Alain. 2016. L'analyse orientée objetopératoire de Círculos Ceifados de Rodolfo Caesar. Música Theorica, v. 1, no 2, p. 6998.

34. Thomaz, Leandro Ferrari. 2007. Aplicação à música de um sistema de espacialização sonora baseado em ambisonics. Master Thesis, Universidade de São Paulo.

35. Thoresen, Lasse; Hedman, Andreas. Spectro-morphological analysis of sound objects: an adaptation of Pierre Schaeffer's typomorphology. Organised Sound 12(2), p. 129-141. 